\title{
Aplikasi Game Puzzle Pengenalan Perangkat Komputer Berbasis Android
}

\author{
Burhan Arifin, Zulfikar, Agus Sifaunajah \\ Fakultas Teknologi Informasi Universitas KH. A. Wahab Hasbullah \\ Correspondence Author: agus.syifa85@gmail.com
}

\begin{abstract}
Mobile device technology is growing rapidly, especially with the emergence of smartphones with Android operating system. Users, in this case, can download a variety of basic applications available easily in the google play store. But most are available in the form of less educational games. Even often the negative impact on users, especially for children who still can not distinguish positive and negative. Thus the researchers create a puzzle game application that can provide entertainment and education to users, especially children. The puzzle game application introduces this selected computer device built using Construct 2 game engine converted with Phonegap into Apk files. Application of this application by installing puzzle game application on a smartphone with operating system specification android version 4.4.2 KitKat.
\end{abstract}

Keywords: Educational Game, Computer Device, Construct 2

\section{INTISARI}

Teknologi perangkat mobile semakin berkembang pesat, apalagi dengan munculnya smartphone dengan sistem operasi android. Pengguna dalam hal ini dapat mengunduh berbagai aplikasi dasar tersedia dengan mudah di google play store. Namun kebanyakan tersedia dalam bentuk game yang kurang mendidik. Bahkan sering kali berakibat negatif pada pengguna khususnya untuk anakanak yang masih belum bisa membedakan positif dan negatif. Maka dari itu peneliti membuat sebuah aplikasi game puzzle yang bisa memberikan hiburan dan edukasi kepada pengguna khususnya anak-anak. Aplikasi game puzzle mengenalkan perangkat komputer yang dipilih ini dibangun menggunakan game engine Construct 2 dikonversi dengan Phonegap menjadi file Apk. Penerapan aplikasi ini dengan memasang aplikasi game puzzle di smartphone dengan spesifikasi sistem operasi android versi 4.4.2 Kitkat.

Kata Kunci : Game Edukasi, Perangkat Komputer, Construct 2

\section{Pendahuluan}

Perkembangan teknologi informasi dan komunikasi yang semakin maju telah memunculkan berbagai media baru (game online) tidak hanya berbasis PC (Portable Computer) tetapi perkembangan teknologi smartphone yang semakin mutakhir dan terjangkau menambah kompleks kehidupan media. Tak heran lagi zaman sekarang pengguna smartphone tidak hanya orang dewasa tapi juga anak-anak, pengawasan orang tua dengan maksud mengenalkan teknologi sekarang sangat diperlukan. Kesalahan yang sering dilakukan orang tua yaitu memberi kebebasan anak yang identik dengan bermain menggunakan smartphone hanya untuk mengakses game tanpa dibekali arahan dan manfaatnya.Munculnya kepribadian kurang baik yang di tunjukkan anak-anak sekarang ini bisa dipicu pada sebuah game yang menjadikan mereka melupakan terhadap kehidupan sosial dalam kehidupan sebenarnya, 
terlebih lagi jika game yang dikonsumsi berunsur kekerasan dikhawatirkan dapat berpengaruh pada pembentukan perilaku agresif anak.

Permainan merupakan salah satu faktor yang cukup penting dalam tumbuh kembang anak. Salah satunya dengan memanfaatkan penggunaan game edukasi puzzle yang dapat menunjang proses pembelajaran terhadap anak. Game puzzle adalah salah satu mainan edukatif yang dapat merangsang kemampuan logika/matematik anak yang dimainkan dengan cara membongkar pasang kepingan puzzle berdasarkan pasangannya.

\section{Kajian Teori}

Bagian ini membahas tentang penjelasan landasan teori yang berisi berbagai konsep dasar dan teori yang berkaitan dalam pembuatan Aplikasi Game Puzzle Pengenalan Perangkat Komputer Berbasis Android.

\subsection{Landasan Teori}

Game merupakan aplikasi yang paling banyak digunakan dan dinikmati para pengguna media elektronik saat ini. Perkembangan game juga dipengaruhi oleh para pengembang software game yang mulai banyak tumbuh. Para pengembang menawarkan paket game yang berbasis komersil maupun non komersil.Di era tahun 2000-an, game mulai banyak bermunculan, baik game 2D maupun 3D. Console game juga sangat berkembang pesat, sehingga industri kreatif ini dapat menghasilkan pendapat yang luar biasa. Untuk membuat game yang baik pasti membutuhkan SDM yang baik pula serta tentunya dana yang tidak sedikit. Beberapa software house pengembang game saat ini mulai khawatir dengan sumber daya yang semakin sedikit dan pembelajaran tentang dasar-dasar game juga tidak banyak. Edugames video game jenis ini dibuat dengan tujuan spesifik sebagai alat pendidikan, baik untuk belajar mengenal warna untuk balita, mengenal huruf dan angka, matematika, sampai belajar bahasa asing. Developer yang membuatnya harus memperhitungkan berbagai hal agar game ini benar-benar dapat mendidik, menambah pengetahuan dan meningkatkan keterampilan yang memainkannya. Target segmentasi pemain harus pula disesuaikan dengan tingkat kesulitan dan design visual ataupun animasinya. Contoh Edugames : Bobi Bola, Dora the explorer, Petualangan Billy dan Tracy. Puzzle video game jenis ini sesuai namanya berintikan mengenai pemecahan teka-teki, baik itu menyusun balok, menyamakan warna bola, memecahkan perhitungan matematika, melewati labirin, sampai mendorong-dorong kotak masuk ke tempat yang seharusnya, itu semua termasuk dalam jenis ini. Sering pula permainan jenis ini juga ada unsur permainan dalam video game petualangan maupun game edukasi. Tetris, Minesweeper, Bejeweled, Sokoban dan Bomberman.

\subsection{Alat Pembuatan Game}

Sebuah alat pembuatan permainan adalah aplikasi perangkat lunak khusus yang membantu atau memfasilitasi pembuatan video game. Beberapa tugas ditangani oleh alat termasuk konversi aset seperti model 3D, tekstur, ke dalam format yang dibutuhkan oleh permainan, mengedit dan skrip tingkat kompilasi. Hampir semua alat-alat pengembangan permainan dikembangkan oleh pengembang kustom untuk satu permainan. Meskipun alat dapat digunakan kembali untuk kemudian permainan, mereka hampir selalu mulai sebagai sumber daya untuk satu permainan. Sementara banyak Cots paket yang digunakan dalam produksi seperti permainan-paket 3D seperti Maya dan 3D Studio Max, grafik editor seperti Photoshop dan IDE seperti Microsoft Visual Studio mereka tidak dianggap sebagai alat pengembangan permainan semata-mata karena mereka telah menggunakan permainan di luar pembangunan. Alat permainan atau mungkin tidak akan dirilis bersama dengan pertandingan final, tergantung pada apa alat ini digunakan. Untuk permainan kontemporer, biasanya untuk mencakup tingkat setidaknya editor dengan permainan yang membutuhkan mereka.

Construct 2 adalah sebuah game engine yang bersifat open source dan sering digunakan untuk membuat game untuk desktop maupun smartphone. Construct 2 sendiri mempunyai

ISSN Print $\quad: 1979-7141$ 
fitur untuk membuat game tanpa melakukan programming karena Construct 2 bersifat drag $n$ drop. Sebagai gantinya Construct 2 mempunyai event sheet yang merupakan pengganti dari source files di bahasa pemrograman. Di dalam event sheet ini terdapat daftar event apa saja yang bisa digunakan dan kondisi apa saja yang bisa terjadi dalam event tersebut. Logika event seperti AND dan OR maupun sub-event memungkinkan pembuatan sistem yang kompleks tanpa belajar bahasa pemrograman yang lebih sulit. Ada juga fitur group dimana fitur tersebut dapat digunakan untuk mengelompokkan dan mengatur event dan menyalakan serta mematikan lebih dari satu event Game yang dibuat di Construct 2 dapat dirilis ke Windows Store, Facebook, Chrome Webstore dan website buatan sendiri. Construct 2 juga dapat digunakan untuk mengekspor game yang awalnya berbasis HTML5 menjadi game mobile untuk Android dan iOS dan Windows Phone maupun untuk Wii U. Tetapi untuk mengekspor game ke platform lainnya harus membeli sebuah personal license yang cukup mahal karena penggunaan komersil tidak diijinkan oleh pengembang Construct 2 tanpa bukti sebagai seorang developer game. Kalaupun ada pengguna yang menerbitkan game dengan in-app purchase yang resmi hanya dibatasi pendapatannya sampai dengan $\$ 5.000$ saja. Lebih dari itu sang pengguna harus meng-upgrade lisensinya menjadi business edition license. Construct 2 juga mengijinkan penggunanya untuk menaruh advertisement atau iklan di gamegame buatan mereka dengan plugin iAds untuk project yang dikhususkan untuk iOS dan Microsoft Pubcenter untuk proyek mereka yang dibuat untuk Windows Phone. Selain itu para pengguna Construct 2 juga dapat menghubungkan proyek mereka dengan Google Play Store dan Apple Game Center untuk membuat sistem achievement atau membuat ranking dari skor para pemain yang telah mengunduh aplikasi mereka.

\subsection{Pustaka Rujukan}

Puzzle game jenis ini sesuai namanya berintikan mengenai pemecahan teka-teki, baik itu menyusun balok, menyamakan warna bola, memecahkan perhitungan matematika, melewati labirin, sampai mendorong-dorong kotak masuk ke tempat yang seharusnya, itu semua termasuk dalam jenis ini. Game puzzle pernah digunakan dengan menggunakan metode steepest Ascent hill climbing yaitu suatu metode pencarian berdasarkan nilai heuristik suatu fungsi yang memberikan nilai untuk perkiraan suatu solusi, metode ini sering digunakan untuk permasalahan optimasi.(Uriawan Wisnu dkk.2015). Puzzle juga digunakan dengan metode pencarian atau pelacakan yang merupakan salah satu teknik untuk menyelesaikan permasalahan AI(Hidayat Wahyono.2014). Dalam bidang lain puzzle juga menggunakan teknik typo. Typo merupakan suatu keadaan dimana terdapat kesalahan ketik pada suatu kata sehingga menyebabkan arti dari kata tersebut berubah (Resna Saputa Wilyan).

\section{Metodologi}

Pada tahapan ini menjelaskan analisa terhadap kebutuhan sistem. Berguna untuk mengetahui dan memahami kebutuhan perangkat lunak yang nantinya digunakan oleh pengguna maupun dalam pembuatan. Pengumpulan data dalam tahap ini bisa melakukan sebuah observasi, atau studi literatur yang sudah dilakukan sebelumnya. Analisis sistem akan memberikan informasi berkaitan dengan pengenalan komputer dengan media game.

\subsection{Alat dan Bahan}

Bahan penelitian yang digunakan dalam proses penelitian ini berasal dari studi jurnal, buku pendukung, dan observasi. Dalam melakukan penelitian ini, alat yang digunakan untuk keberhasilan penelitian adalah sebagai berikut :

a. Perangkat Keras (Hardware) Laptop Lenovo dengan spesifikasi Processor AMD E1-2100 1,0 GHZ Hd Grapich 1,00 GHz Display size 11,6" W LED Hard Disk 500GB RAM 2 GB

b. Perangkat Lunak (Software)

Windows 7 Ultimate 32 bit, Construct 2, format factory, Intel XDK, Paint. 


\subsection{Prosedur Penelitian}

Penelitian ini merupakan penelitian pengembangan (development research) dengan maksud untuk mengembangkan pengetahuan tentang manajemen sains dalam aplikasi game puzzle pengenalan perangkat komputer berbasis android.

1. Studi literatur

2. Observasi

3. Pengumpulan data

Keperluan data dalam pembuatan aplikasi yaitu mengunduh gambar dan tutorial dari sumber internet.

4. Pengolahan data

Adapun alur pengolahan data dapat dilihat pada gambar berikut :

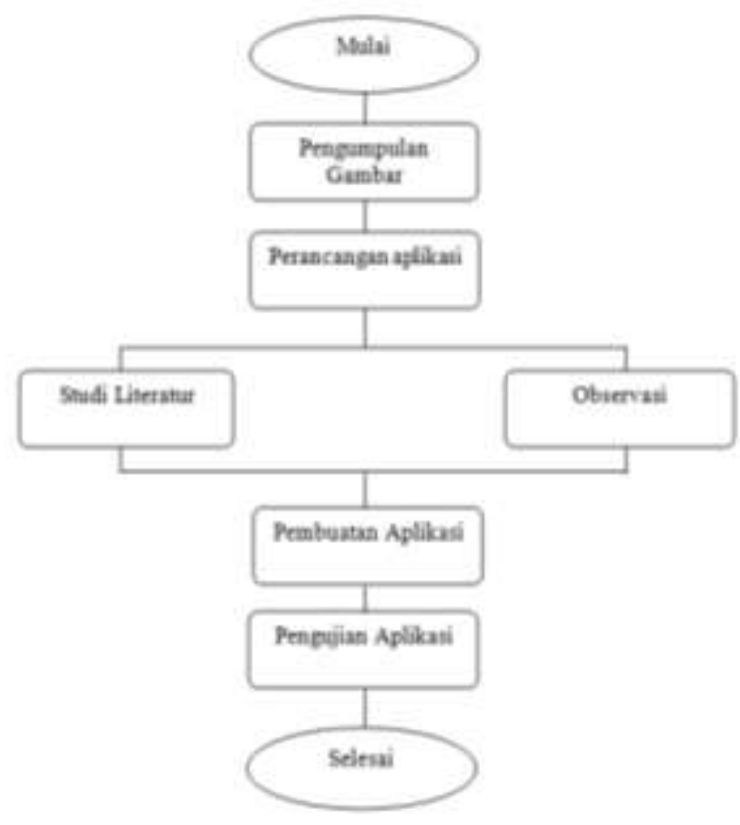

Gambar 3.2.1 Bagan Pengolahan Data

\subsection{Perancangan Interface Aplikasi}

Perancangan Interface Aplikasi Game Puzzle ini dibangun dengan menggunakan game engine Construct 2. Adapun sebagian bentuk perancangan form yang dibutuhkan adalah sebagai berikut :

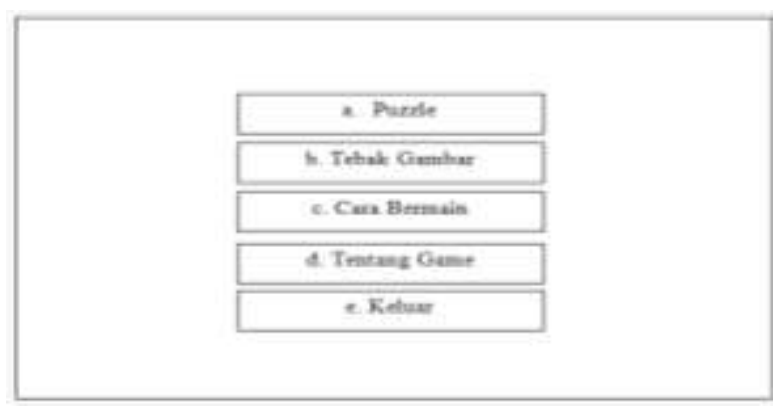

Gambar 1 : Perancangan Layar menu 
Pada gambar dibawah ini perangkaian puzzle berukuran 3x3 dimana cara menjalankan permainan ini dari beberapa potongan gambar sesuaikan gambar yang telah di potong kemudian rangkai secara keseluruhan serta pada saat meletakan potongan gambar tersebut score juga akan menampilkan hasilnya sementara waktu juga akan berjalan.

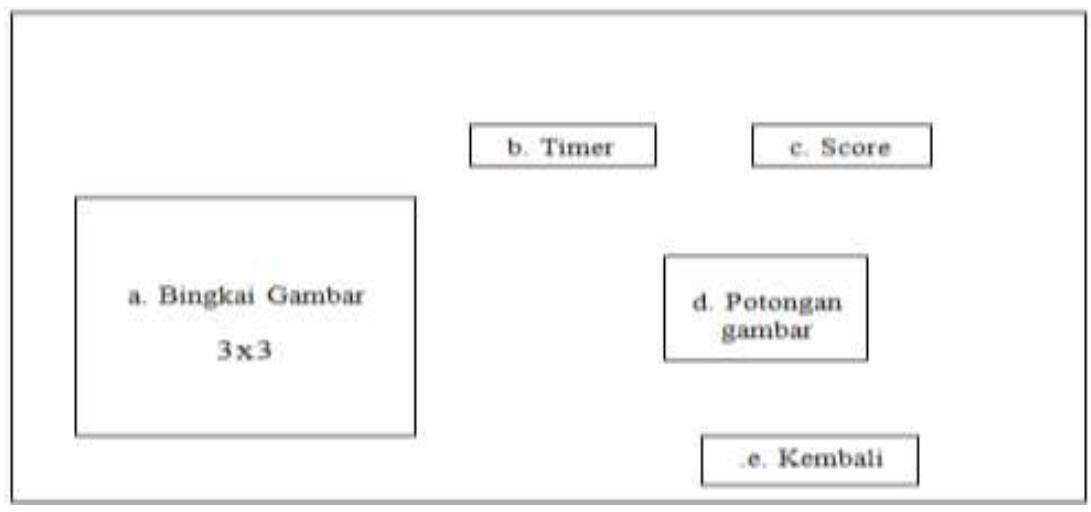

Gambar 2 : Perancangan Level Mudah

Perancangan tebak gambar dibawah ini menampilkan gambar perangkat komputer dan textbox untuk menjawab soal.

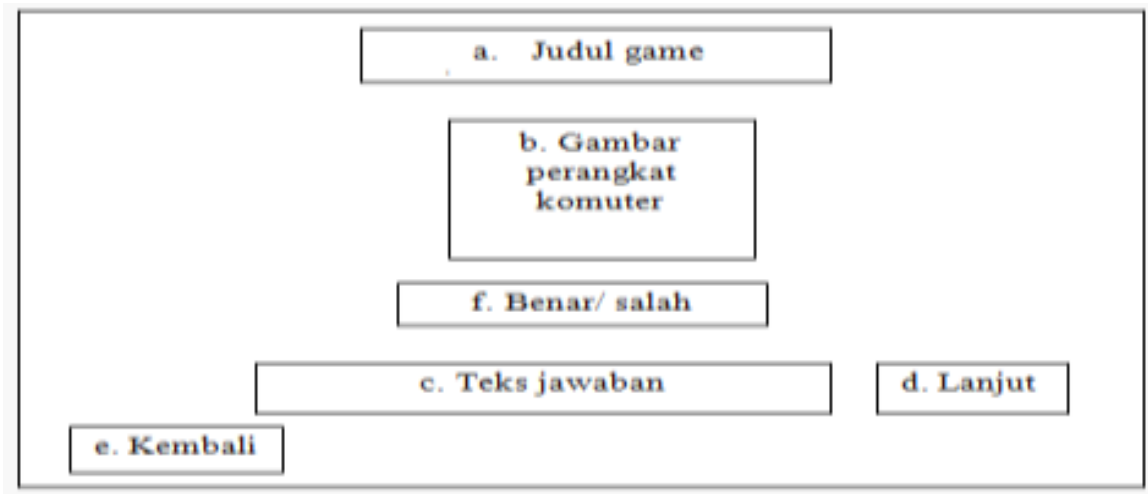

Gambar 3 : Perancangan Tebak Gambar

\section{Hasil dan Pembahasan}

Pada tahapan ini akan dilakukan pengujian terhadap sistem aplikasi permainan puzzle tahap ini dilakukan setelah tahap perancangan selesai dilakukan. Adapun sebagian hasil yang didapatkan adalah sebagai berikut :

\subsection{Implementasi Antar Muka}

Implementasi antar muka merupakan tahap dimana sebuah sistem siap dioperasikan pada tahapan yang sebenarnya, sehingga bisa diketahui apakah sistem yang telah dibuat ini sudah sesuai dengan apa yang sudah dirancang sebelumnya. Pada tampilan menu berisi permainan puzzle dan tebak gambar fitur cara bermain dan tentang game. 


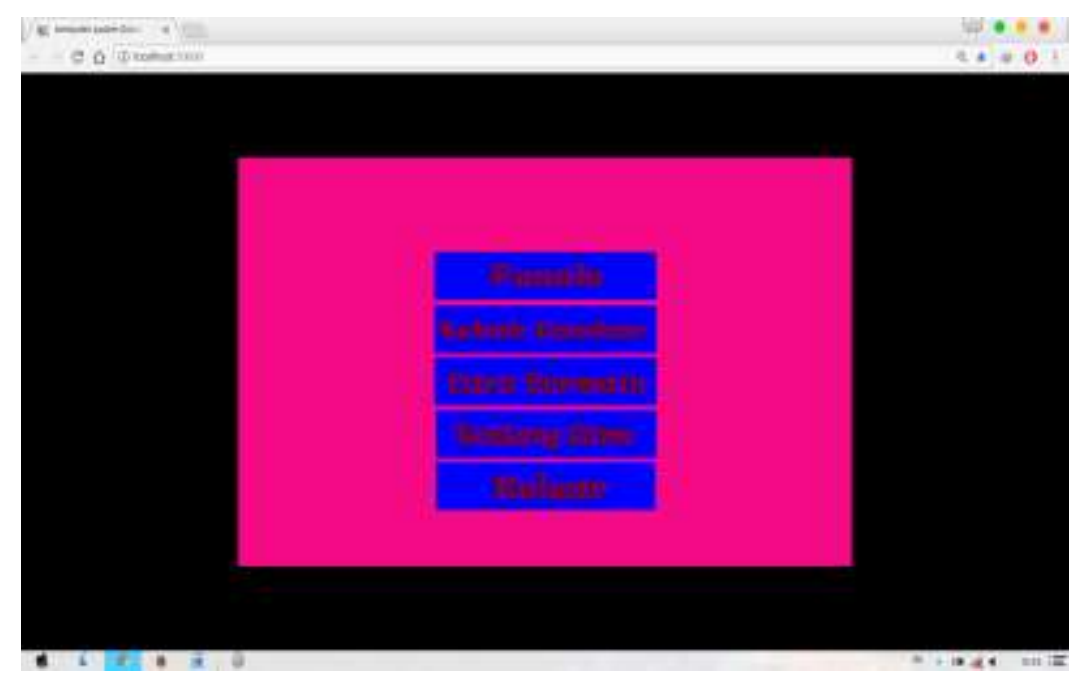

Gambar 4 : Tampilan Layout Utama

Pada gambar dibawah hasil interface level mudah yaitu proses perangkaian puzzle berukuran 3x3 dimana cara menjalankan permainan ini dari beberapa potongan gambar disamping anda tinggal meletakkan kepada posisi asli dan sesuaikan gambar yang telah di potong dan kemudian rangkai secara keseluruhan serta pada saat meletakan potongan gambar tersebut score juga akan menampilkan hasilnya sementara waktu juga akan berjalan.

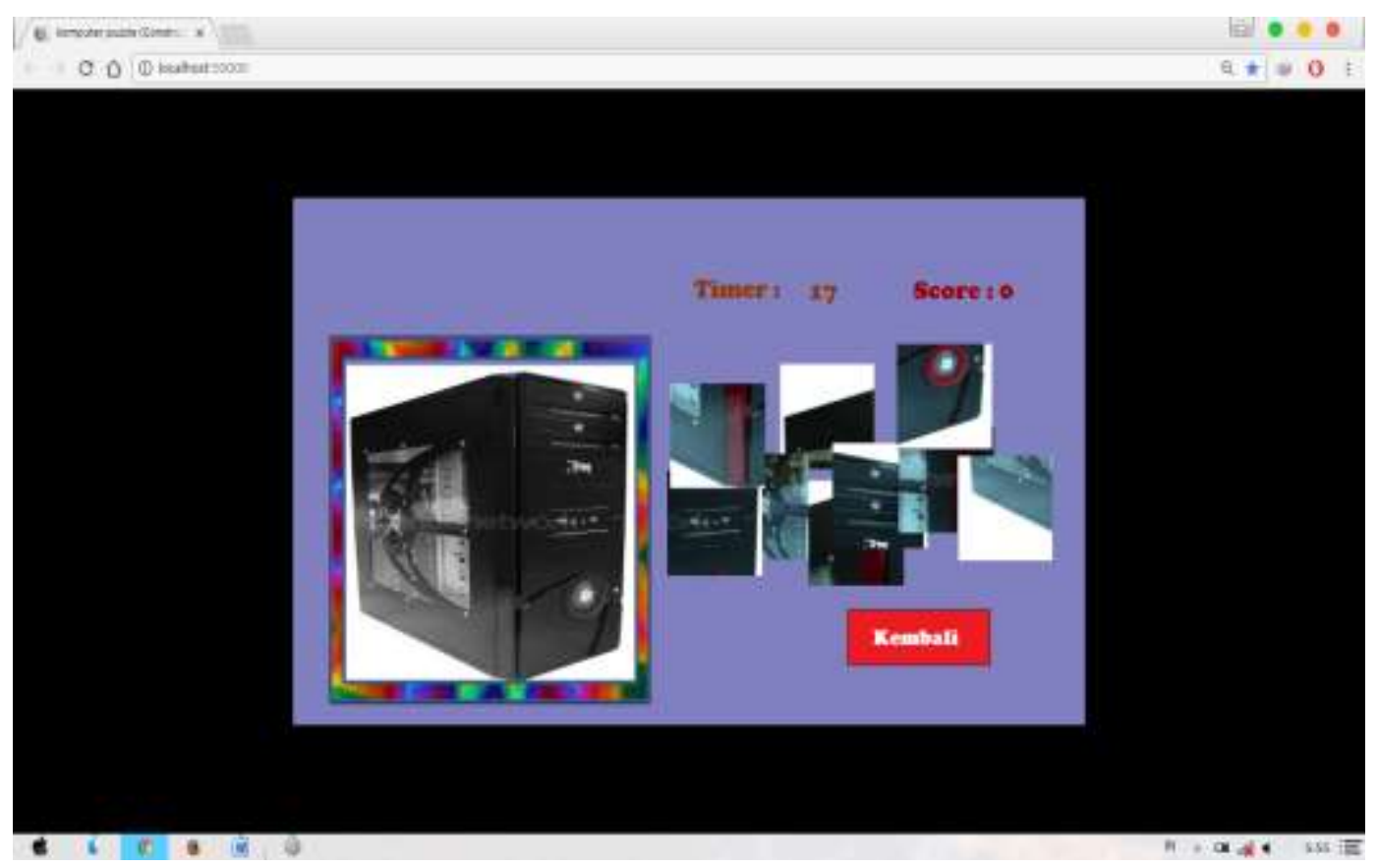

Gambar 5 : Tampilan Level Mudah

Hasil perancangan interface tebak gambar dibawah ini menampilkan gambar perangkat komputer dan text box untuk menjawab soal. 


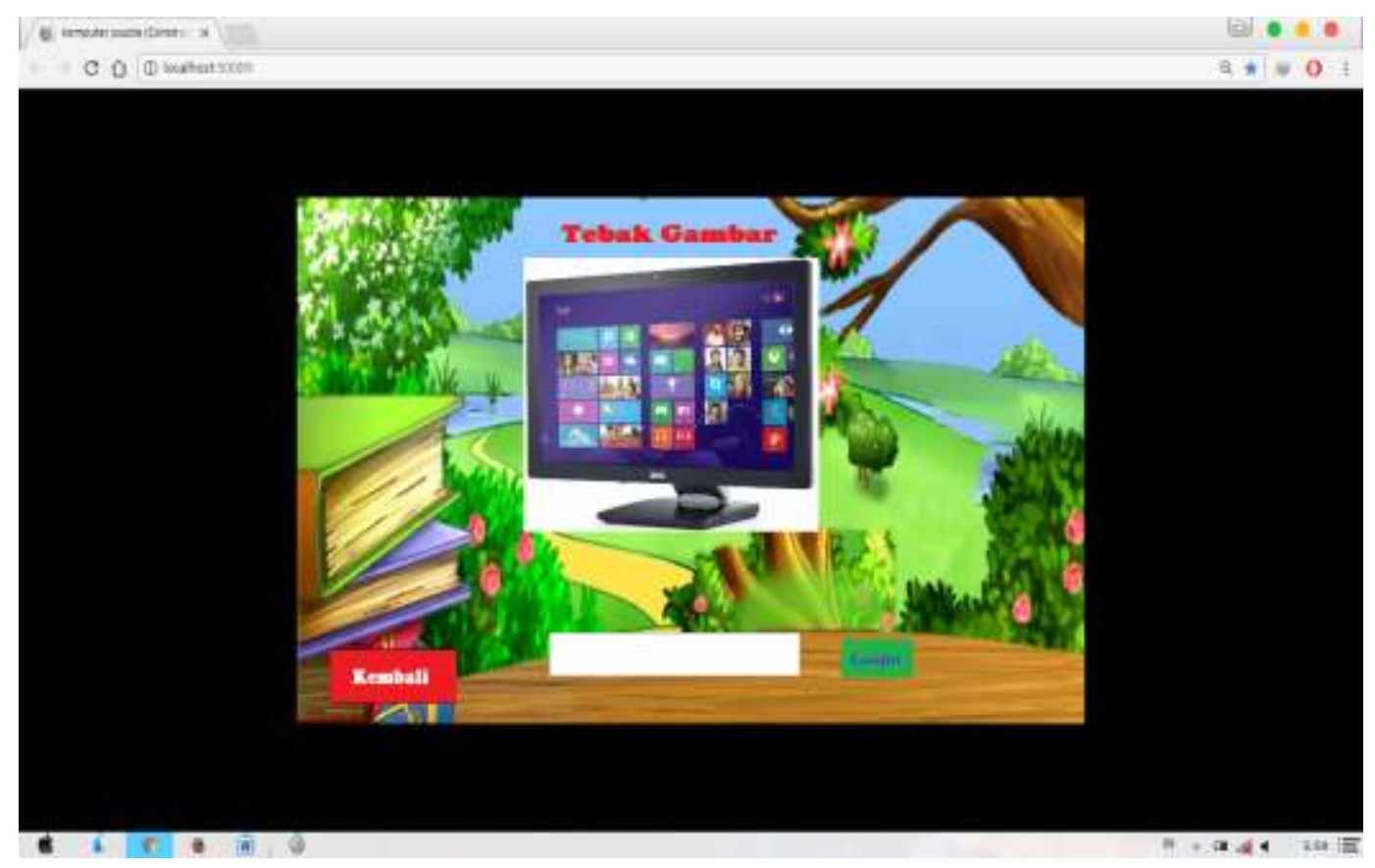

Gambar 6 : Tampilan Tebak Gambar

\subsection{Pengujian Black Box Testing}

Pengujian sistem dilakukan dengan metode Black Box Testing yang hasilnya disajikan dalam tabel sebagai berikut.

Tabel 1 : Pengujian sistem dengan Metode Black Box Testing

\begin{tabular}{|c|c|c|c|c|c|}
\hline \multirow{2}{*}{ No } & \multirow{2}{*}{ Modul yang diuji } & \multirow{2}{*}{ Deskripsi pengujian } & \multicolumn{2}{|c|}{ Berhasil } & \multirow{2}{*}{ Saran } \\
\hline & & & $\mathbf{Y a}$ & Tidak & \\
\hline \multirow{5}{*}{1} & \multirow{5}{*}{ Layout Menu } & Sprite puzzle & $\mathrm{Ya}$ & & \\
\hline & & Sprite tebak gambar & $\mathrm{Ya}$ & & \\
\hline & & Sprite cara bermain & $\mathrm{Ya}$ & & \\
\hline & & Sprite tentang game & $\mathrm{Ya}$ & & \\
\hline & & Sprite keluar & $\mathrm{Ya}$ & & \\
\hline \multirow{5}{*}{2} & \multirow{5}{*}{ Layout Mudah } & Sprite gambar1 & $\mathrm{Ya}$ & & \\
\hline & & Border gambar1 & $\mathrm{Ya}$ & & \\
\hline & & Text timer & $\mathrm{Ya}$ & & \\
\hline & & Text score & $\mathrm{Ya}$ & & \\
\hline & & Canvas & $\mathrm{Ya}$ & & \\
\hline
\end{tabular}


Lanjutan Tabel 1 : Pengujian sistem dengan Metode Black Box Testing

\begin{tabular}{|c|c|c|c|c|c|}
\hline \multirow{2}{*}{ No } & \multirow{2}{*}{ Modul yang diuji } & \multirow{2}{*}{ Deskripsi pengujian } & \multicolumn{2}{|c|}{ Jawaban } & \multirow{2}{*}{ Saran } \\
\hline & & & Ya & Tidak & \\
\hline \multirow{7}{*}{3} & \multirow{7}{*}{$\begin{array}{l}\text { Layout tebak } \\
\text { gambar }\end{array}$} & Sprite gambar & $\mathrm{Ya}$ & & \\
\hline & & $\begin{array}{l}\text { Text judul tebak } \\
\text { gambar }\end{array}$ & $\mathrm{Ya}$ & & \\
\hline & & Text box 1 & $\mathrm{Ya}$ & & \\
\hline & & Sprite lanjut & $\mathrm{Ya}$ & & \\
\hline & & Sprite benar & $\mathrm{Ya}$ & & \\
\hline & & Sprite salah & $\mathrm{Ya}$ & & \\
\hline & & Sprite kembali & $\mathrm{Ya}$ & & \\
\hline \multirow{6}{*}{4} & \multirow{6}{*}{$\begin{array}{l}\text { Layout cara } \\
\text { bermain }\end{array}$} & Text 2 & $\mathrm{Ya}$ & & \\
\hline & & Text 3 & $\mathrm{Ya}$ & & \\
\hline & & Text 4 & $\mathrm{Ya}$ & & \\
\hline & & Text 5 & $\mathrm{Ya}$ & & \\
\hline & & Text 6 & $\mathrm{Ya}$ & & \\
\hline & & Sprite kembali & $\mathrm{Ya}$ & & \\
\hline \multirow{2}{*}{5} & \multirow{2}{*}{ Layout top score } & Txtscore & $\mathrm{Ya}$ & & \\
\hline & & Sprite kembali & $\mathrm{Ya}$ & & \\
\hline
\end{tabular}

\subsection{Analisis dan Pengujian pada Smartphone}

Pada tahapan ini adalah pengujian aplikasi dengan memasang game puzzle pengenalan perangkat komputer di Smartphone. Tujuan pengujian ini adalah untuk menguji hasil hasil implementasi pada smartphone, apakah sesuai atau dapat diterapkan di masing-masing resolusi smartphone.

Tabel 2 : Pengujian pada Smartphone

\begin{tabular}{|l|l|}
\hline \multicolumn{1}{|c|}{ Spesifikasi } & \multicolumn{1}{c|}{ Keterangan } \\
\hline Resolusi & $800 \times 480$ \\
\hline Sistem Operasi & Android KitKat 4.4.2 \\
\hline Memori RAM & $1 \mathrm{~GB}$ \\
\hline
\end{tabular}




\section{Kesimpulan}

Dari hasil perancangan dan pengujian sistem permainan puzzle pengenalan perangkat komputer diatas, maka dapat di ambil kesimpulan sebagai berikut :

1. Dari penelitian ini, telah dihasilkan sebuah Game Edukasi puzzle berbasis sistem operasi Android versi Kitkat 4.4.2 yang dapat digunakan untuk pembelajaran anak usia dini.

2. Game Edukasi yang tercipta mengajarkan tentang pengembangan logika dan yang meliputi pembelajaran mengenal perangkat komputer serta didukung dengan musik dengan antar muka yang mudah dimengerti dan dioperasikan oleh anak usia dini .

3. Game Edukasi ini telah diuji dengan menggunakan metode pengujian Black Box Testing. 


\section{DAFTAR PUSTAKA}

Alapi, Muh. Bardi H, Aplikasi Game Puzzle Berbasis Android. STMIK AKAKOM Yogyakarta.

Cecilia Utami Dewi, Rancang Bangun Permainan Puzzle The Key Berbasis Android, Universitas Ciputra, UC Town, CitraLand, Surabaya.

Deryando Capringo dan Agustinus Noertjahyana, Pembuatan Game Shooter Edukasi Virus Komputer, Universitas Kristen Petra, Surabaya.

Leo agung.M, 2010. Mahir dalam 7 hari microsoft windows 7. Andi yogyakarta dengan MADCOMS

Musthafa Ananda Erfan, 2015, Pengaruh Intensitas Bermain Game Online dan Pengawasan Orang Tua Terhadap Perilaku Agresif Anak, Semarang, Universitas Diponegoro.

Pratama, I Wayan Putra Darsa 2016, Game Puzzle Pesona Bali Berbasis Android. STMIK AKAKOM Yogyakarta.

Rifai Wafda Adita, 2015, Pengembangan Game Edukasi Lingkungan Berbasis Android, Fakultas Teknik Universitas Negeri Yogyakarta.

Safaat H. Nazruddin, 2012, Pemrograman Aplikasi Mobile Smartphone dan Tablet PC Berbasis Android, Bandung, INFORMATIKA.

Saputro dwi, 2015, Pembuatan Game Edukasi"Bahasa Inggris Anak"Berbasis Android Menggunakan Construct 2, Universitas Surakarta.

Sibero Ivan C, 2010, Membuat Game 2D menggunakan Game Maker, MediaKom, Yogyakarta.

Sulianta feri \& Wicaksono Yudhy, 2010, Teknnik Reparasi Ekspor impor konversi untuk semua kebutuhan. PT Elex Media Komputindo. Jakarta

Wahyono Hidayat, 2014. Rancang Bangun Game Puzzle Menggunakan Platform Android, Jurusan Teknik Elektro Fakultas Teknik Universitas Tanjungpura.

Wilyan Resna Saputa, Aplikasi Word Puzzle Game Berbasis Android, Jurusan Manajemen Informatika, Fakultas Ilmu Terapan.

Wisnu Uriawan, Adam Faroqi, Risa Fathonah. 2015. Pembuatan Game Slider Puzzle Menggunakan Metode Steepest Ascent Hill Climbing Berbasis Android, Jurusan Teknik Informatika, Fakultas Sains dan Teknologi, Universitas Islam Negeri Sunan Gunung Djati Bandung. 